\title{
Professional Marginality of Graduates of Higher Education Institutions
}

\section{Професійна маргінальність випускників закладів вищої освіти}

\author{
Olena Blynova \\ Олена Блинова \\ Dr. in Psychology, Professor \\ доктор психологічних наук, \\ професор \\ E-mail:elena.blynova@gmail.com \\ orcid.org/0000-0003-3011-6082 \\ Researcher ID: A-5188-2019 \\ Kherson State University, \\ Kherson, Ukraine \\ 27, Universytetska str., \\ Kherson, 73003 \\ Svitlana Kaminska \\ Ph.D. in Psychology \\ Херсонський державний \\ університет, м. Херсон, \\ Україна \\ вул. Університетська, 27, \\ м. Херсон, 73003 \\ Світлана Камінська \\ кандидат психологічних наук \\ E-mail:skaminskav@gmail.com \\ orcid.org/0000-0002-5747-8801 \\ Researcher ID: A-5637-2019
}

Kherson Regional Psychiatric Hospital, Kherson, Ukraine

65, John Howard str., Kherson, 73488
Херсонська обласна психіатрична лікарня, м. Херсон, Україна вул. Джона Говарда, 65, м. Херсон, 73488

Original manuscript received December 02, 2018 Revised manuscript accepted January 15, 2019 


\section{ABSTRACT}

The article is devoted to the problem of forming positive professional identity of future specialists. It is stated, that part of senior courses students of higher education institutions does not connect their professional future with the specialty they are getting, but still they remain among students, realizing their non-educational and non-professional goals. It is studied out, that such a person's condition acquired the notion of professional marginality. The aim of the investigation is to analyze the influence of professional demand for graduates on the display of identity/marginality. The status of the problem was analyzed, the definitions of "professional marginality» and "professional demand" were formulated, their components were concretized, the results of empirical investigation were provided. It was stated that professional marginality was a display or a form of identity disorder (impossibility of active search and choice, launch of identification, cognitive and affective alteration) and the disorder of identity dynamics, i.e. of the processes of distinguishing between roles and rules, corresponding to identity.

The diagnostics of professional identity/marginality implied evaluating the following components: person's competency within the profession, his/ her idea about him/herself as a professional, attitude to the profession's role in the society. 318 students of senior courses took part in the empirical investigation. The differences between the groups of "professionally identical» and "professionally marginal» students were stated according to professional demand parameters, namely the satisfaction with the degree of professional potential realization; the belonging to the professional community; the experience of professional demand; self-attitude as a competent and authoritative professional; evaluation of professional activity results; perception of others' attitude towards him/her as an authoritative professional.

Key words: higher education institution, students of senior courses, professional identity, professional marginality, professional demand.

\section{Вступ}

Стратегічним завданням вищої школи є формування фахівців із високим рівнем професійної ідентичності, які усвідомлено залучаються до соціально-професійної сфери суспільства, розуміють суспільну значущість своєї справи, свої можливості самореалізації, бажають реалізовувати свої професійні знання та навички, для яких профресійна праця в структурі життєвих цінностей займає гідне місце. 
Проте в освітньому просторі вищої школи активно присутня певна кількість студентів випускних курсів, вибір спеціальності для яких був випадковим, вони майже вирішили для себе, що за тим фахом, який вони здобувають, працювати надалі не планують. I при цьому, вони залишаються у складі студентів, реалізуючи свої позанавчальні та позапрофесійні цілі. Таке положення людини на межі між соціальними статусами отримало назву професійної маргінальності. У наукових працях О. Єрмолаєвої (Ермолаева, 2011) цей феномен визначається як несформованість або розпад професійної ідентичності, що пов'язано з неадекватним виконанням соціальних функцій професії. Недостатня розробленість соціально-психологічної сутності професійної маргінальності студентів випускних курсів і суспільна значущість проблеми зумовили актуальність дослідження.

Перш ніж охарактеризувати професійну маргінальність, вважаємо за потрібне звернутися до історичних передумов уживання поняття «маргінальність» у суспільних науках. Уперше поняття маргінальності застосував Р. Парк стосовно адаптації мігрантів, розглядаючи його як стан переходу, як положення людини на межі «двох світів» (Park, 1928). Полісемантичність слова «маргінальність» надає можливість його подвійної інтерпретації: воно може трактуватися як межовий стан (маргінальність - перехідність), а також як периферійне положення соціального суб’єкта (маргінальність - периферійність) (Baumeister, 1986). Л. Кемалова і Ю. Парунова наголошують на тому, що маргінальність має атрибутивний характер. Важко уявити соціум, який не містить явища маргінальності, маргінальних груп, маргінальних особистостей, маргінальної свідомості та поведінки, тобто маргінальність визначається як соціокультурне і соціально-психологічне явище, що постійно й нерозривно супроводжує різні види соціалізації (Кемалова \& Парунова, 2010). 
Для цілей нашої розвідки у соціально-психологічному контексті найвдалішою є концепція статусно-рольової маргінальності, що акцентує увагу на вивченні людини, чий соціальний статус ще не визначений, чия поведінка визначається приналежністю до двох соціальних ролей. Маргінальність означає не просто перехід з однієї соціальної структури до іншої, вона підкреслює незавершеність цього переходу, внаслідок чого маргінальна особистість відчуває складнощі у процесі адаптації (Zepeda, 2016).

На сьогодні актуальною стає розробка соціально-психологічних проблем маргінальності, оскільки точкою концентрації проблем маргінальності є саме людина, а через неї - соціум. Маргінальність виникає внаслідок проміжного, межового стану людини у суспільстві, тому є внутрішньою характеристикою людського «Я», що свідчить про незадоволеність основних соціальних і духовних потреб особистості. Для індивідів, які перебувають у стані зміни соціального статусу, характерними соціально-психологічними рисами є: тривожність, невпевненість, невизначеність, розгубленість, сумніви у власній цінності, комплекс ізольованості, самотність. Також можливі особистісна дезорганізація, дезадаптація, зниження рівня соціальних очікувань і рівня домагань (Кемалова \& Парунова, 2010; Ложкін \& Волянюк, 2010).

Дослідники не обмежуються традиційними соціальними та культурологічними проблемами маргінальності, а звертають увагу ще й на соціально-психологічні проблеми, зокрема, формування поведінки особистості в ситуаціях маргіналізації, екзистенціальні аспекти (Могдалева, 2008), взаємозв'язок маргінальності з соціальною мобільністю (Пілецька, 2008), соціальне конструювання маргінальності (Кемалова \& Парунова, 2010), маргінальний статус (Шульга, 2000).

Отже, професійна маргінальність є проявом або формою професійної мобільності особистості, коли вона потрапляє у проміжне положення між двома соціальними 
статусами (Kelo, Teicher \& Wachter, 2006). Звертаючись до предмета нашого дослідження, це соціальні положення «студент» $\mathrm{i}$ «рахівець», тобто ми розглядаємо маргінальну ситуацію та пов'язану з нею зміну соціально-професійної ідентичності, коли випускник, як майбутній фахівець із певної спеціальності, не може або не хоче професійно реалізувати себе у цій спеціальності, заперечує її важливість, бажає змінити фах тощо.

Мета статті - проаналізувати вплив усвідомлення професійної затребуваності випускників закладів вищої освіти на їх прояви ідентичності / маргінальності.

\section{Завдання статті}

1) Розкрити сутність професійної маргінальності;

2) дібрати комплекс психодіагностичних методик дослідження;

3) емпірично перевірити особливості впливу професійної затребуваності на прояви ідентичності / маргінальності випускників закладів вищої освіти.

\section{Методи та методики дослідження}

Емпіричне дослідження проводилось на базі Херсонського державного університету, в дослідженні взяли участь 318 студентів IV курсу (випускники-бакалаври) та II курсу (випускники-магістри) різних факультетів і спеціальностей. Для досягнення мети та вирішення поставлених завдань психодіагностичний комплекс дослідження склали такі методики: діагностичний тест «Ідентичність / маргінальність професіонала» О. Срмолаєвої для з'ясування ступеня маргінальності студентів (Ермолаева, 2011); опитувальник «Професійна затребуваність особистості» $Є$. Харітонової, Б. Ясько для оцінки професійної компетентності та приналежності до професійної спільноти (Харитонова, 2014). Для статистичного аналізу отриманих результатів застосовано однофакторний дисперсійний і порівняльний аналіз (комп'ютерна програма SPSS (версія 19.0)). 


\section{Результати та дискусії}

Професійна маргінальність безпосередньо пов'язана 3 процесами становлення ідентичності (неможливість активного пошуку і вибору) та порушення динаміки професійної ідентичності, тобто виявлення ролей, правил і прототипів, відповідних ідентичності.

Окреслимо основні підходи до визначення професійної ідентичності, яка є актуальною темою сучасних досліджень у психології. 3 погляду Т. Березиної, вона виконує такі функції, як розвиток «професійного почуття», тобто емоційного прийняття себе як людини, що займається певною справою, усвідомлення відповідної ментальності, впевненість у професійній компетентності, самостійності й ефективності, переживання своєї професійної цілісності та визначеності (Березина, 2008). Через професійну ідентичність та ідентифікацію Г. Ложкін і Н. Волянюк розкривають поняття «професіонал». Із погляду авторів, професійної ідентичності можна досягти лише за умови, коли провідною основою ідентифікації є професійна діяльність, що виступає як основний чинник психологічного благополуччя, а також за наявності перетворюючого психологічного потенціалу особистості (Ложкін \& Волянюк, 2010). Е. Зеєр i C. Ренке визначають професійну ідентичність як професійний «Я-образ», що включає професійні стереотипи й унікальність власного «Я»; усвідомлення своєї тотожності з професійним образом «Я» (Зеер, 2006; Ренке, 2018).

О. Калашніков, С. Мінюрова (Kalashnikov \& Minyurova, 2017 ) розглядають явище депрофесіоналізаціїі, пов'язуючи його безпосередньо з кризою професійної ідентичності та кризою професійної етики.

Акцентуємо на тому, що при дослідженні професійної ідентичності багато науковців, зокрема О. Блинова, А. Борисюк, О. Єрмолаєва, Т. Богданова, П. Зћивкович та ін., виокремлюють три основні компоненти цього складного інтегративного утворення - ставлення до свого професійного «Я» $з$ погляду вже засвоєних знань, умінь і навичок; 
ставлення до себе у структурі професійної спільноти; ставлення до ролі та значущості професії у соціумі (Блинова, 2011; Борисюк, 2010; Jermolajeva, Bogdanova, 2017, Živković, 2018). Професійна ідентичність при цьому виступає як внутрішня схема, у якій відображено уявлення людини про те, якою вона повинна бути, що вміти робити і як поводитися в професійній спільноті для того, щоб ефективно реалізувати себе в професії. Тобто, у цьому підході ми виокремлюємо три складові - компетентність людини у професії, її уявлення про себе як професіонала, ставлення до ролі професії у суспільстві.

Найбільш узагальнене визначення професійної ідентичності, яке максимально розширює межі цього поняття, надає О. Єрмолаєва. Розглядаючи цей термін у контексті системи «людина - професія - суспільство», вона відзначає її сутнісну психосоціальну структуру, в якій сфокусовано основні відношення професіонала. Ця дослідницька позиція дає змогу О. Срмолаєвій заявити про професійну ідентичність як про системну характеристику суб'єктносоціально-діяльнісної відповідності, тобто трактувати її не просто як характеристику прийняття професійних цінностей, але й як гармонійну ідентифікацію з діяльністю (інструментальна ідентичність), соціумом (зовнішня ідентичність) й із самим собою (внутрішня ідентичність). Виходячи 3 цього, науковець визначає професійну маргінальність як особистісну позицію непричетності та психологічної неналежності до суспільно значущої для цієї професії моралі й професійних норм, або внутрішне прийняття професійних норм іншого професійного середовища (Ермолаева, 2011).

Отже, можна констатувати, що сучасне студентство, яке набуває певних теоретичних знань у закладах вищої освіти, недостатньо використовує їх у реальній практичній діяльності. Молодь маргіналізується, оскільки виходить на ринок праці «неозброєною», з незначним набором ресурсів, які вона може використовувати у процесі адаптації в новому для неї професійному середовищі. Для сучасної 
студентської молоді й освітня, й професійна сфери виступають своєрідними агентами маргіналізації. Несформованість установки на засвоєння професії призводить до появи типових рис професійного маргінала: 1) безвідповідальне ставлення до навчання (орієнтація на отримання диплома про вищу освіту); 2) нерозуміння специфіки майбутньої професії; 3) орієнтація на іншу професію; 4) відсутність бажання працювати за фахом після закінчення університету (це свідчить, з одного боку, про усвідомлення неконкурентоспроможності й непрестижності майбутньої професї̈, 3 іншого - про власну нездатність реалізовувати професійні функції); 5) нездатність (небажання) постійно збільшувати обсяг знань, набувати практичних навичок; 6) невпевненість у власному професійному майбутньому (Бутиліна, 2012).

Відділом моніторингу якості освіти Херсонського державного університету проведено анкетування серед студентів, у якому взяли участь 62\% загального контингенту випускників денної форми навчання. За результатами опитування 56,7\% випускників планують після закінчення університету працювати за фахом. Незважаючи на їх бажання працювати за обраною спеціальністю, 51,5\% із них зазначають, що їм може завадити недостатня кількість реальних робочих місць. У іншій сфері планують працювати 19,2\% і ще 24,1\% - не вирішили, що вони далі робитимуть. Тобто, серед випускників університету, які взяли участь в анкетуванні, близько 40\% не планують працювати за спеціальністю або мають певні сумніви щодо такої можливості. Звісно, на такі результати впливають об'єктивні та суб'єктивні чинники. Серед об'єктивних чинників, крім реального браку робочих місць, можна відзначити поглиблення розриву між системою освіти та сферою виробництва.

Нами з'ясовано, що професійна ідентичність є психосоціальною структурою, у якій поєднуються три сфери самореалізації фахівця: інструментальна (усвідомлення себе професіоналом, який володіє необхідною сукупністю 
компетентностей, знань, навичок, умінь в обраній спеціальності); індивідуальна (усвідомлення себе як особистості частиною своєї професійної спільноти, прийняття цілей, цінностей, норм і правил професійної поведінки); соціальна (розуміння ролі й значущості своєї професії та професіоналів для розвитку суспільства).

Відповідно, професійна маргінальність відображає певний «розрив» (деструкцію, порушення) системних зв'язків: «людина і професія», «професіонал і соціум», «професія і соціум», тобто, виокремлюються три види професійної маргінальності - інструментальна (невідповідність своєї професійної підготовки вимогам професії); індивідуальна (несформованість, неприйняття, заперечення цілей і цінностей професійної спільноти, небажання дотримуватись норм професійної етики, прагнення змінити фах); соціальна (низький рівень оцінки значущості професії у суспільному розвитку) (рис. 1).

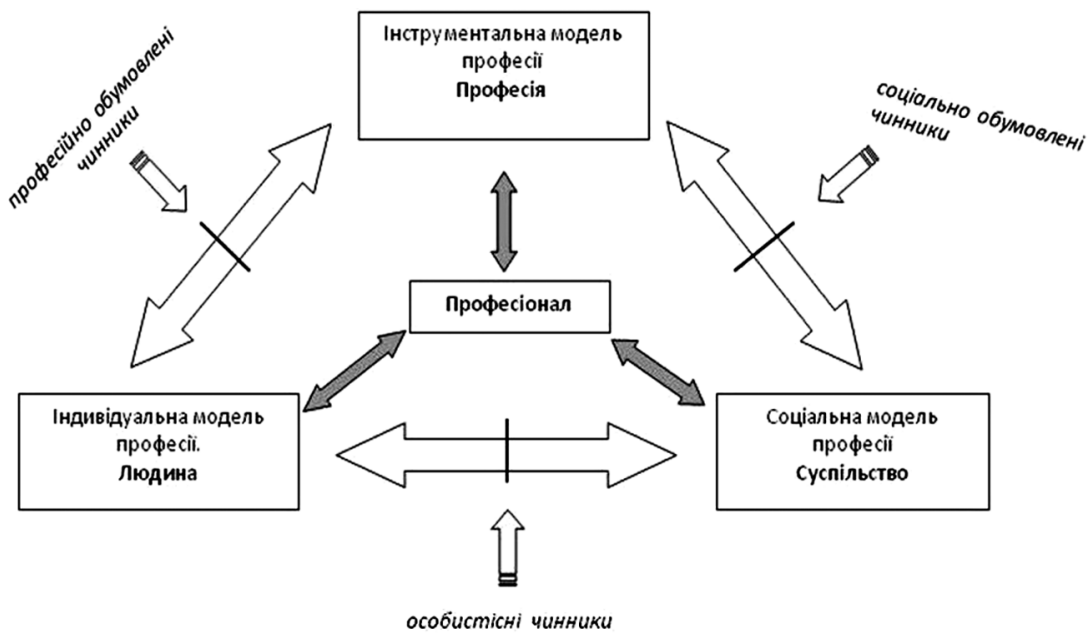

Puc. 1. Модель професійної ідентичності / професійної маргінальності

Виходячи з цього, виокремлюємо три групи соціально-психологічних чинників, що детермінують прояви про- 
фесійної ідентичності / професійної маргінальності: 1) соціально обумовлені чинники (положення у суспільстві професіоналів певного фаху, престижність їх праці, рівень соціальної та матеріальної забезпеченості з боку держави, можливість працевлаштування за обраною спеціальністю); 2) професійно обумовлені чинники (прийняття фахівцем смислів, цінностей, поглядів професійної спільноти, набуття відповідних професійно значущих рис особистості); 3) особистісні чинники (певні особистісні риси, які сприяють набуттю професійної ідентичності або, навпаки, провокують виникнення професійної маргінальності).

Отже, важливим чинником, що впливає на набуття майбутнім фахівцем професійної ідентичності, є усвідомлення власної значущості як професіонала, переживання професійної затребуваності. Затребувана особистість - це людина, яка позитивно ставиться до себе як до значущого для інших професіонала; задоволена ступенем реалізації професійного потенціалу; оцінює результати своєї професійної діяльності як суспільно корисні; відчуває приналежність до професійної спільноти; позитивно ставиться до себе як до компетентного й авторитетного професіонала; позитивно сприймає ставлення до себе як до професіонала з боку колег, керівництва, близького соціального оточення (Харитонова, 2014).

Узагальнюючи результати теоретичного аналізу проблеми, доходимо висновку, що феномен професійної маргінальності є особливим станом особистості чи групи, який характеризується певним ступенем виключення із соціально-професійної сфери суспільства, неможливістю (небажанням) реалізовувати професійні знання та навички, втратою ціннісного компонента праці, нездатністю ідентифікувати себе за професійною ознакою, орієнтацією виключно на оплату праці, а не на її сутність.

Для емпіричного дослідження взято методику «Професійна ідентичність / маргінальність» О. Срмолаєвої, де професійна ідентичність має три виміри - індивідуальний, 
соціальний та інструментальний, i, відповідно, містить у собі три основні шкали: «професіонал і соціум», «соціум і професія», «людина і професія»; сім підшкал: «статус і динаміка», «професійна мотивація», «професійний вчинок», «кар'єра», «мораль», «альтернативний вибір», «бути або видаватися». Опитувальник містить 56 запитань, кожне з яких орієнтоване на розкриття одного з трьох зв'язків: між людиною та професією, між професіоналом і суспільством, між суспільством і професією. Обробка результатів відбувається за допомогою ключа до методики.

Крім того, нами застосовано опитувальник «Професійна затребуваність особистості» Є. Харітонової, який $€$ багатошкальною методикою, належить до групи стандартизованих особистісних тестів, дозволяє діагностувати рівень виразності професійної затребуваності особистості та їі компонентів: ставлення до себе як професіонала, що реалізував свій потенціал; приналежність до професійної спільноти і суспільства загалом; переживання професійної затребуваності; ставлення до себе як до компетентного професіонала; ставлення до себе як до авторитетного професіонала; оцінювання професійної діяльності та їі результатів; сприйняття ставлення інших до себе як до значущого професіонала; самоставлення як до значущого для інших професіонала. Опитувальник містить 47 тверджень, до кожного з яких подається 4 варіанти відповіді. Обробка результатів відбувається за допомогою стандартизованого ключа до методики.

На наступному етапі дослідження ми провели порівняльний аналіз двох підвибірок досліджуваних із використанням методу крайніх груп: I група - високий рівень професійної ідентичності, до якої увійшли 72 студенти $(22,6 \%$ від загальної вибірки дослідження); II група - високий рівень професійної маргінальності, до якої увійшли 58 осіб (18,4\% від загальної вибірки дослідження). Для розподілу брали до уваги загальний рівень ідентичності / маргінальності за методикою О. Срмолаєвої. Був здійснений порів- 
няльний аналіз двох груп досліджуваних за шкалами методики «Професійна затребуваність особистості» С. Харітонової, статистичну значущість різниці між групами перевірено за допомогою t-критерію Стьюдента. Результати порівняння двох вибірок представлено у таблиці 1.

Таблиця 1. Порівняльна таблиця професійно ідентичних і професійно маргінальних випускників закладів вищої освіти за показниками професійної затребуваності

\begin{tabular}{|c|c|c|c|c|c|}
\hline $\begin{array}{c}\text { № } \\
3 / \Pi\end{array}$ & Назва показника & $\begin{array}{c}\text { Профе- } \\
\text { сійно } \\
\text { ідентичні. } \\
\text { Група I } \\
\text { (n=72) }\end{array}$ & $\begin{array}{c}\text { Професій- } \\
\text { но маргі- } \\
\text { нальні. } \\
\text { Група II } \\
(\mathrm{n}=58)\end{array}$ & $\begin{array}{c}\text { t-кри- } \\
\text { терій }\end{array}$ & $\begin{array}{c}\text { Рівень } \\
\text { значу- } \\
\text { щості }\end{array}$ \\
\hline 1. & $\begin{array}{c}\text { Задоволеність } \\
\text { реалізацією } \\
\text { професійного } \\
\text { потенціалу (ЗРПП) }\end{array}$ & 25,9 & 22,8 & 2,49 & $\mathrm{p} \leq 0,05$ \\
\hline 2. & $\begin{array}{c}\text { Приналежність } \\
\text { до професійної } \\
\text { спільноти (ППС) }\end{array}$ & 24,2 & 21,9 & 2,43 & $\mathrm{p} \leq 0,05$ \\
\hline 3. & $\begin{array}{c}\text { Переживання } \\
\text { професійної } \\
\text { затребуваності (ППЗ) }\end{array}$ & 25,1 & 22,3 & 2,59 & $\mathrm{p} \leq 0,05$ \\
\hline 4. & $\begin{array}{c}\text { Професійна } \\
\text { компетентність (ПК) }\end{array}$ & 26,7 & 26,5 & - & - \\
\hline 5. & $\begin{array}{c}\text { Професійний } \\
\text { авторитет (ПА) }\end{array}$ & 23,9 & 21,6 & 2,08 & $\mathrm{p} \leq 0,05$ \\
\hline 6. & $\begin{array}{c}\text { Оцінка результатів } \\
\text { професійної } \\
\text { діяльності (ОРПД) }\end{array}$ & 30,1 & 25,2 & 3,29 & $\mathrm{p} \leq 0,01$ \\
\hline 7. & Ставлення інших (СІ) & 25,8 & 22,9 & 2,34 & $\mathrm{p} \leq 0,05$ \\
\hline 8. & Самоставлення (СС) & 23,6 & 24,3 & - & - \\
\hline
\end{tabular}

Як бачимо з таблиці, «професійно ідентичні» (група 1) випускники закладу вищої освіти відрізняються від «професійно маргінальних» (група 2) за показником «задово- 
леність реалізацією професійного потенціалу» $\left(\mathrm{t}_{\text {емп. }}=2,49\right.$; $\mathrm{p} \leq 0,05)$. Це свідчить про те, що професійно ідентичні студенти краще орієнтуються в обраній спеціальності, часто вже мають практичний досвід, набутий під час навчання, виробничих практик і реальної роботи за фахом. Саме ті випускники, які прагнуть засвоїти свою професію якомога досконаліше, вже у процесі навчання працюють за спеціальністю.

Ми можемо підсумувати, що професійно ідентичні випускники задоволені досягнутим професійним статусом, вважають, що наявних можливостей достатньо для виконання тих професійних завдань, які постають у діяльності, дотримуються думки, що життя надає можливість для професійної самореалізації, загалом такі особи задоволені своїм рівнем професійної компетентності. Крім того, вони впевнені, що в період навчання скористались усіма можливостями для того, щоб удосконалити та реалізувати свій професійний потенціал, а тому вважають, що їх рівень кваліфікації дасть їм змогу вирішити будь-які складні завдання.

За другою шкалою «Приналежність до професійної спільноти» отримано статистично значущі відмінності між двома досліджуваними групами студентів-випускників $\left(\mathrm{t}_{\text {емп. }}=2,43 ; \mathrm{p} \leq 0,05\right)$. Такі результати доводять, що рівень суб'єктивної ідентифікації з професійною спільнотою у професійно ідентичних випускників є вищим порівняно з групою професійно маргінальних студентів. Професійно ідентичні випускники підкреслюють важливість усвідомлення себе представником певної професійної спільноти та пишаються приналежністю до неї, вважають, що своєю працею вони здатні бути корисними для суспільства, розуміють значущість наступності в діяльності та з повагою ставляться до своїх попередників у професії, задоволені тим, що оточуючі люди, зокрема керівництво й інші студенти, враховують їх думку при прийнятті відповідальних рішень. 
За третьою шкалою «Переживання професійної затребуваності» між групами 1 і 2 також отримано статистично значущі розбіжності $\left(\mathrm{t}_{\text {емп. }}=2,59 ; \mathrm{p} \leq 0,05\right)$. Професійно маргінальні випускники університету відчувають, що не здатні знайти застосування своїм професійним знанням, умінням і навичкам, вони не бачать цінності ні у своїй професійній діяльності, ні в їі результатах (наявний «розрив» професія - суспільство), відчувають незатребуваність, непотрібність результатів своєї професійної діяльності для інших людей. Водночас такі студенти переживають, що професійні навички можуть бути суттєво втрачені. Професійно маргінальні студенти відрізняються низьким рівнем почуття власної гідності та самоповаги у професійній діяльності.

За четвертою шкалою «Професійна компетентність» нами визначено, що відмінності виявилися статистично незначущими. Обидва значення мають середню оцінку $\left(\mathrm{X}_{1}=26,7 ; \mathrm{X}_{2}=26,5\right)$. Як професійно ідентичні, так і професійно маргінальні випускники закладів вищої освіти відзначають, що вони середньою мірою володіють усією системою засобів діяльності, щоб вирішувати будь-які професійні завдання; середньою мірою задоволені рівнем своєї професійної компетентності, досягнутим рівнем кваліфікації, своїм досвідом тощо. Ми вважаємо, що оскільки дослідницьку вибірку складають саме студенти випускних курсів, у яких реального професійного досвіду ще, дійсно, недостатньо, то, мабуть, професійно ідентичні випускники більш критично оцінюють свою професійну компетентність, водночас у професійно маргінальних випускників або проявляється феномен соціальної бажаності, що може провокувати саме середні результати, або існує орієнтація на іншу професію чи спеціальність, у якій теж професійна компетентність ще не досягнута. Досліджувані обох груп відзначають наявність хвилювань, сумнівів стосовно того, що наявних професійних знань і досвіду не вистачить для вирішення професійних завдань, для процесу підготовки та прийняття рішень. 
П'ята шкала «Професійний авторитет» показує статистично значущі відмінності між групами професійно ідентичних і професійно маргінальних випускників $\left(\mathrm{t}_{\text {емп. }}=2,08 ; \mathrm{p} \leq 0,05\right)$. Професійно ідентичні випускники вважають, що інші студенти (або колеги, якщо у студента є реальний професійний досвід) поважають і цінують їх як фахівців, вони задоволені оцінкою своєї діяльності з боку інших людей, а також тим, що керівництво та колеги спираються на їх думку, коли приймають відповідальні рішення. Вони відчувають, що є певною мірою авторитетом для інших, оскільки до них часто звертаються за допомогою, порадою та підтримкою.

Шоста шкала «Оцінка результатів професійної діяльності» виявила наявність статистичної різниці між студентами, які належать до групи професійно ідентичних, i студентами, яких ми можемо назвати професійними маргіналами $\left(\mathrm{t}_{\text {емп. }}=3,29 ; \mathrm{p} \leq 0,01\right)$. Слід підкреслити, що професійно ідентичні випускники високо оцінюють обрану професію, її значення для розвитку суспільства, соціальну значущість результатів діяльності фахівців у своїй професії та намагаються саме у ній досягти значних успіхів, вони позитивно оцінюють власні результати професійної діяльності. Професійно маргінальні випускники не бачать цінності своєї професійної діяльності для соціуму, для себе особисто, для своєї родини, вони сумніваються у правильності обрання професійного шляху та виконання професійних дій, а також мають сумніви щодо здатності реалізувати себе у цьому напрямку.

За сьомою шкалою «Ставлення інших» нами виявлено, що групи 1 і 2 також відрізняються між собою, цю різницю підтверджено статистично $\left(\mathrm{t}_{\text {емп. }}=2,34 ; \mathrm{p} \leq 0,05\right)$. Професійно ідентичні випускники підкреслюють високий рівень задоволеності зворотним зв'язком щодо якості та результатів їх професійної діяльності з боку близьких людей, однокурсників, колег, керівництва, вони вважають, що заслуговують на високу позитивну оцінку як фахівця. Про- 
фесійно маргінальні випускники відчувають негативну оцінку їх професійної діяльності, вважають, що їх думка не цікавить ані колег, ані керівництво та виказують сумнів, що у цій галузі взагалі можливо знайти застосування їх здібностям.

За восьмою шкалою «Самоставлення» нами не виявлено відмінностей між досліджуваними групами $\left(\mathrm{X}_{1}=23,6\right.$; $\left.\mathrm{X}_{2}=24,3\right)$. Ми вважаємо, що такі результати пов'язані 3 тим, що професійне самоставлення дуже взаємопов'язане із загальною самооцінкою, тому кожна людина завдяки механізмам компенсації прагне до збереження високого рівня самоповаги. Зауважимо, що обидва показники знаходяться у зоні середніх значень, тобто як професійно ідентичні випускники університету, так і група професійно маргінальних студентів, переважно позитивно ставляться до себе, вважають, що їх праця приноситиме користь для суспільства і що вони зможуть реалізувати свій потенціал. Мабуть, відмінності між групами полягають у тому, що професійно ідентичні випускники прагнуть до реалізації саме у тій діяльності, яка відповідає обраному фаху, а професійно маргінальні або вже націлені на зміну фахового спрямування, або ще перебувають у стані прийняття рішень, але після цього все ж сподіваються на позитивну самореалізацію у діяльності.

\section{Висновки}

На основі теоретичного аналізу й емпіричних результатів дослідження нами з'ясовано, що оцінка професіонала на континуальній шкалі ідентичність / маргінальність можлива за трьома критеріями: номінально-професійним, за яким людина і соціум упізнають професію, а професіонал ідентифікує себе з нею; соціально-прийнятним, за яким оцінюється рівень відповідності професіонала запитам того соціального середовища, у якому він реалізується; зовнішнім (загальноцивілізаційним) критерієм, що відображає рівень відповідності професіонала світовим 
стандартам, у контексті яких професія розглядається як загальнолюдська цінність.

Визначено сутність професійної маргінальності випускників закладів вищої освіти, яка є порушенням професійної ідентичності та полягає у «розриві» взаємозв'язків у цілісній системі «людина - професія - суспільство» .

Показано, що до чинників професійної маргінальності випускників закладів вищої освіти належить професійна затребуваність особистості, що визначається як багаторівнева, ієрархічна метасистема суб'єктивних ставлень особистості до себе як до значущого для інших професіонала.

Установлено статистично значущі відмінності між групами професійно ідентичних i професійно маргінальних випускників за такими параметрами професійної затребуваності: «усвідомлення рівня професійної компетентності», «задоволеність професійною самореалізацією», «суб’єктивна ідентифікація 3 професійною спільнотою», «оцінка ролі та значення обраної професії для розвитку суспільства», «задоволеність зворотним зв'язком щодо якості та результатів професійної діяльності з боку однокурсників, колег, керівництва», що доводить наявність «розриву» в єдиній системі професійної ідентифікації фрахівця «людина - професія - соціум» .

Перспективи подальших досліджень можуть бути пов'язані зі створенням системи профілактики формування професійної маргінальності майбутніх фахівців.

\section{Література}

Березина Т. С. Экспериментальное исследование формирования динамики профессиональной идентичности педагогов в ситуации обучения в вузе. Вестник Московского государственного университета. Серия: Психологические науки. 2008. № 3. С. 162-171.

Блинова О. С. Трудова міграція населення України у соціально-психологічному вимірі: монографія. Херсон : РІПО, 2011. 488 с.

Борисюк А. С. Професійна ідентичність медичного психолога: соціально-психологічний аналіз. Чернівці : Книги-XXI, 2010. 440 с.

Бутиліна О. В. Професійна маргінальність студентів. Вісник Львівського університету. Серія: Соціологічна. 2012. Вип. 6. С. 81-87. 
Ермолаева Е. П. Оценка реализации профессионала в системе «человек - профессия - общество». Москва : Институт психологии РАН, 2011. 176 c.

Зеер Э. Ф. Личностно-развивающее профессиональное образование: монография. Екатеринбург : Изд-во РГППУ, 2006. 169 с.

Кемалова Л. И., Парунова Ю. Д. Личность маргинала и возможности ее социализации в условиях транзитивного общества: монография. Симферополь - Керчь : Таврия, 2010. 228 с.

Ложкин Г. В., Волянюк Н. Ю. Конфликтные источники профессионального маргинализма. Горизонты образования. 2010. № 2 (30). С. 43-48.

Могдалева И. В. Маргинальность в современной российской и украинской философии. Ученые записки таврического национального университета ил. В. И. Вернадского. Серия: Философия. Социология. 2008. T. 21 (60). № 1. С. 231-239.

Пілецька Л. С. Маргінальність у контексті проблеми соціальної мобільності особистості. Збірник наукових праць : філософія, соиіологія, психологія. Івано-Франківськ, 2011. Вип. 16. Ч. 1. С. 5-15.

Ренке С. О. Професійний образ «Я» як предмет психології та становлення особистісної ідентичності майбутнього фахівця. Проблели сучасної психологї : Збірник наукових праць Кам'янець-Подільського національного університету ілені Івана Огієнка, Інституту психологї ілені Г. С. Костюка НАПН України / За наук. ред. С. Д. Максименка, Л. А. Онуфрієвої. Кам'янець-Подільський : Акcioмa, 2018. Вип. 39. С. 257-271. DOI 10.32626/2227-6246.201839.257-271.

Харитонова Е. В. Психология социально-профессиональной востребованности личности: монографія. Москва : Институт психологии PAH, 2014. $411 \mathrm{c}$.

Шульга М. Маргінальність як криза ідентичності. Соціологія: теорія, летоди, маркетинг. 2000. № 3. С. 166-170.

Baumeister, R. (1986). Identity. Cultural Change and Struggle for Self. New York : Oxford, p. 18-19.

Jermolajeva, J., \& Bogdanova, T. (2017). Philosophy of the Profession and Professional Knowledge in the Structure of Professional Identity of Hei Teachers in Riga and Smolensk. Economics and Culture, 14 (1), 41-49. DOI 10.1515/jec-2017-0004.

Kalashnikov, A. I., \& Minjurova, S. A. (2017). Professional Commitment and Professional Marginalism in Teachers. Psihologicheskaja nauka i obrazovanie - Psychological Science and Education, 22 (5), 5-13. DOI 10.17759/pse.2017220501.

Kelo, M., Teicher, U., \& Wachter, B. (2006). Eurodata. Student mobility in European higher education. Bonn : Lemmens Verlags und Mediengesellshaft. 
Park, R. E. (1928). Human migration and the marginal man. American Journal of Sociology, 33 (6), 879-893. Chicago.

Zepeda, S. (2016). Principals' Perspectives: Professional Learning and Marginal Teachers on Formal Plans of Improvement. Research in Educational Administration \& Leadership, 1 (1), June, 25-59.

Živković, P. (2018). Concurrent validity of the student teacher professional identity scale. International Journal of Cognitive Research in Science, Engineering and Education, 6 (1). DOI 10.5937/ijcrsee1801013Z.

\section{References}

Berezina, T. S. (2008). Jeksperimental'noe issledovanie formirovanija dinamiki professional'noj identichnosti pedagogov $\mathrm{v}$ situacii obuchenija $v$ vuze [Experimental research on the formation of dynamics of teachers' professional identity in a situation of training in the institution of higher educational]. Vestnik Moskovskogo gosudarstvennogo universiteta. Serija: Psihologicheskie nauki-Visnyk of Moscow State University. Series: Philology, 3, 162-171 [in Russian].

Blynova, O. Ye. (2011). Trudova mihratsiia naselennia Ukrainy u sotsialnopsykholohichnomu vymiri [Labor migration of Ukrainian population in socio-psychological dimension]. Kherson : RIPO [in Ukrainian].

Borysiuk, A. S. (2010). Profesiina identychnist medychnoho psykholoha: sotsialno-psykholohichnyi analiz [Professional identity of a medical psychologist: socio-psychological analysis ]. Chernivtsi : Knyhy-XXI [in Ukrainian].

Butylina, O. V. (2012). Profesiina marhinalnist studentiv [Professional marginality of students]. Visnyk Lvivskoho universytetu. Seriia: Sotsiolohichna - Visnyk of Lviv University. Series: Sociological, 6, 81-87 [in Ukrainian].

Ermolaeva, E. P. (2011). Ocenka realizacii professionala $v$ sisteme "chelovek - professija - obshchestvo» [Evaluation of a professional's realization in the system «man - profession - society»]. Moskwa : Institut Psihologii RAN [in Russian].

Zeer, E. F. (2006). Lichnostno-razvivajushchee professional'noe obrazovanie [Personality-based developing professional education]. Ekaterinburg : Kzd-vo RGPPU [in Russian].

Kemalova, L. I., \& Parunova, Ju. D. (2010). Lichnost' marginala i vozmozhnosti ee socializacii $v$ uslovijah tranzitivnogo obshchestva [Personality of a marginal and the possibility of its socialization in the conditions of a transitive society]. Simferopol' - Kerch : Tavrija [in Russian].

Lozhkin, G. V., \& Voljanjuk, N. Ju. (2010). Konfliktnye istochniki professional'nogo marginalizma [Conflict sources of professional marginalism]. Gorizonty obrazovanija - Education horizons, 2 (30), 43-48 [in Russian]. 
Mogdaleva, I. V. (2008). Marginal'nost v sovremennoj rossijskoj i ukrainskoj filosofii [Marginality in modern Russian and Ukrainian philosophy]. Uchenye zapiski Tavricheskogo nacional'nogo universiteta im. V.I. Vernadskogo. Serija: Filosofija. Sociologija-Scientific notes of V. I. Vernadsky Taurida National University. Series: Philosophy, Sociology, 21 (60), 231-239 [in Russian].

Piletska, L. S. (2011). Marhinalnist u konteksti problemy sotsialnoi mobilnosti osobystosti [Marginality in the context of the problem on social mobility of the personality]. Zbirnyk naukovykh prats: filosofiia, sotsiolohiia, psykholohiia - Collection of scientific works: philosophy, sociology, psychology, 16, 5-15 [in Ukrainian].

Renke, S. O. (2018). Profesiinyi obraz «Ya» yak predmet psykholohii ta stanovlennia osobystisnoi identychnosti maibutnoho fakhivtsia [Professional «Me»-image as a subject of psychology and the formation of a future specialist's personality-based identity]. Problemy suchasnoi psykholohii: Zbirnyk naukovykh prats Kamianets-Podilskoho natsionalnoho universytetu im. I. Ohiienka, Instytutu psykholohii imeni H. S. Kostiuka APN Ukrainy - The Collection of Research Papers of Kamianets-Podilskyi National Ivan Ohiienko University and G. S. Kostiuk Institute of Psychology of the National Academy of Educational Sciences of Ukraine, 39, 257-271. DOI 10.32626/22276246.2018-39.257-271 [in Ukrainian].

Haritonova, E. V.(2014). Psihologija social'no-professional'nojvostrebovannosti lichnosti [Psychology of social and professional demand of a personality]. Moskwa : Institut psychologii RAN [in Russian].

Shulha, M. (2000). Marhinalnist yak kryza identychnosti [Marginality as a crisis of identity]. Sotsiolohiia: teoriia, metody, marketynh-Sociology: theory, methods, marketing, 3, 166-170 [in Ukrainian].

Baumeister, R. (1986). Identity. Cultural Change and Struggle for Self. New York : Oxford, p. 18-19.

Jermolajeva, J., \& Bogdanova, T. (2017). Philosophy of the Profession and Professional Knowledge in the Structure of Professional Identity of Hei Teachers in Riga and Smolensk. Economics and Culture, 14 (1), 41-49. DOI 10.1515/jec-2017-0004.

Kalashnikov, A. I., \& Minjurova, S. A. (2017). Professional Commitment and Professional Marginalism in Teachers. Psihologicheskaja nauka i obrazovanie - Psychological Science and Education, 22 (5), 5-13. DOI 10.17759/pse.2017220501 [in Russian, abstr. in English].

Kelo, M., Teicher, U., \& Wachter, B. (2006). Eurodata. Student mobility in European higher education. Bonn : Lemmens Verlags und Mediengesellshaft [in German].

Park, R. E. (1928). Human migration and the marginal man. American Journal of Sociology, 33 (6), 879-893. Chicago. 
Zepeda, S. (2016). Principals' Perspectives: Professional Learning and Marginal Teachers on Formal Plans of Improvement. Research in Educational Administration \& Leadership, 1 (1), June, 25-59.

Živković, P. (2018). Concurrent validity of the student teacher professional identity scale. International Journal of Cognitive Research in Science, Engineering and Education, 6 (1). DOI 10.5937/ijcrsee1801013Z.

\section{АНОТАЦІЯ}

Статтю присвячено проблемі фрормування позитивної професійної ідентичності майбутніх фахівців. Констатовано, що частина студентів випускних курсів закладів вищої освіти не пов'язує своє професійне майбутнє з тією спеціальністю, яку вони здобувають, проте вони залишаються у складі студентів, реалізуючи свої позанавчальні та позапрофесійні цілі. 3'ясовано, що таке положення людини на межі між соціальними статусами отримало назву професійної маргінальності. Метою дослідження є аналіз впливу професійної затребуваності випускників закладів вищої освіти на прояви ідентичності / маргінальності. Проаналізовано стан проблеми, визначено дефінічії «професійна маргінальність» і "професійна затребуваність», конкретизовано їх складові, наведено результати емпіричного дослідження. Установлено, що професійна маргінальність є проявом або фрормою порушення ідентичності, причому можливі два варіанти: порушення становлення ідентичності (неможливість активного пошуку та вибору, запуску ідентифікації, когнітивної й афективної переробки) та порушення динаміки ідентичносmi, тобто прочесів виявлення ролей і правил, відповідних ідентичності.

Діагностика професійної ідентичності / маргінальності передбачала оцінювання таких складових: компетентність людини у професії, ії уявлення про себе як професіонала, ставлення до ролі професії у суспільстві. В емпіричному дослідженні взяли участь 318 студентів випускних курсів. Констатовано відмінності між групами «професійно ідентичних» $i$ "професійно маргінальних» студентів за параметрами профресійної затребуваності, а саме: задоволеністю ступенем реалізації професійного потенціалу; приналежністю до професійної спільноти; переживанням професійної затребуваності; ставленням до себе як до компетентного та авторитетного професіонала; оцінкою результатів професійної діяльності; сприйняттям ставлення інших до себе як до значущого професіонала.

Ключові слова: заклад вищої освіти, студенти випускних курсів, професійна ідентичність, професійна маргінальність, професійна затребуваність. 
Блинова Елена, Каминская Светлана. Профессиональная маргинальность выпускников высших учебных заведений

\section{АННОТАЦИЯ}

Статья посвящена проблеме формирования позитивной профессиональной идентичности будущих специалистов. Показано, что часть студентов выпускных курсов высших учебных заведений не связывает свое профессиональное будущее с той специальностью, которую они получают, при этом они остаются в числе студентов, реализуя свои внеучебные и внепрофессиональные цели. Такое положение человека на границе между социальными статусами получило название профессиональной маргинальности. Целью исследования является анализ влияния профрессиональной востребованности выпускников высших учебных заведений на проявления идентичности / маргинальности. Определены дефиниции "профессиональная маргинальность» и «профессиональная востребованность», конкретизированы их компоненты, приведены результаты эмпирического исследования. Установлено, что профессиональная маргинальность является проявлением или формой нарушения идентичности, причем возможны два варианта: нарушение становления идентичности (невозможность активного поиска и выбора, запуска идентификации, когнитивной и афрективной переработки) и нарушение динамики идентичности, т. е. процессов освоения ролей, правил, соответствующих идентичности.

Диагностика профессиональной идентичности / маргинальности включала в себя оценивание таких компонентов: компетентность в профрессии, представление о себе как о профессионале, отношение $к$ значимости профессии в обществе. В эмпирическом исследовании приняли участие 318 студентов выпускных курсов. Выявлены отличия между группами "профессионально идентичных» и "профессионально маргинальных» студентов по параметрам профессиональной востребованности, а именно: удовлетворенности степенью реализации профессионального потенциала; принадлежности к профессиональному сообществу; отношению к себе как к компетентному и авторитетному профессионалу; оценке результатов профессиональной деятельности.

Ключевые слова: высшее учебное заведение, студенты выпускных курсов, профессиональная идентичность, профессиональная маргинальность, профессиональная востребованность. 